\title{
POSSIBLE EFFECTS OF MOSS ON DISTRIBUTION AND PERFORMANCE OF A THREATENED ENDEMIC PRIMROSE
}

\author{
Andrew P. Rayburn ${ }^{1,3}$, Jacob B. Davidson ${ }^{2}$, and Hillary M. White ${ }^{1}$
}

\begin{abstract}
Mosses may compete with vascular plants for limited soil resources, facilitate vascular plants by buffering extremes in abiotic conditions, and potentially trap seeds and provide safe sites for germination and establishment. We conducted a field study to investigate the effects of moss on the distribution and performance of Primula cusickiana var. maguirei, a threatened endemic perennial forb that occurs in an extremely narrow range within a single canyon in northern Utah, USA. Within the study population, we found that primroses occurred far more often on moss patches than on other substrates and that primroses occurring on moss patches had increased basal area and flower production. Furthermore, analyses revealed that soil under moss patches with primrose present had more organic matter, elevated magnesium concentrations, and lower Ca:Mg ratios. Our results suggest at least 3 hypotheses that may be evaluated through future studies. First, moss may facilitate P. cusickiana var. maguire $i$ via the provision of increased soil resources. Second, moss may trap primrose seeds, leading to the observed pattern of distribution. And third, mosses and the primrose may both be responding to an as-yet-unmeasured habitat factor (e.g., soil depth or microtopography). Our results inform future research on P. cusickiana var. maguirei and have direct implications for the conservation of this threatened species.
\end{abstract}

RESUMEN.-Los musgos pueden competir por los recursos limitados del suelo con las plantas vasculares, pueden favorecer a tales plantas al amortiguar las condiciones extremas que ocurren bajo condiciones abióticas y potencialmente atrapar semillas y proveerles de sitios seguros para la germinación y el establecimiento. Llevamos a cabo un estudio de campo para averiguar los efectos del musgo sobre la distribución y el desempeño de la prímula Maguire (Primula cusickiana var. maguirei), la cual es una planta herbácea perenne y endémica que está en peligro y que tiene una distribución extremadamente limitada dentro de un solo cañón al norte de Utah (EE.UU.). Dentro de la población de estudio, encontramos a P. cusickiana var. maguirei mucho más a menudo en parches de musgos que en otros sustratos, y estas plantas creciendo en parches de musgos tuvieron mayor área basal y más producción de flores. Más aún, los análisis revelaron que el suelo que se encontraba bajo musgos y P. cusickiana var. maguirei tenía más materia orgánica, concentraciones elevadas de magnesio y una disminución de la relación Ca:Mg. Nuestros resultados sugieren al menos tres hipótesis que podrían evaluarse mediante estudios futuros. Primero, el musgo puede favorecer a P. cusickiana var. maguirei al aumentar la provisión de recursos del suelo. Segundo, puede que los musgos atrapen semillas de P. cusickiana var. maguirei, conllevando así al patrón de distribución observado. Por último, es posible que tanto los musgos como $P$. cusickiana var. maguirei estén respondiendo a un factor del hábitat que aun no medimos (e.g. la profundidad del suelo o la microtopografía). Nuestros resultados brindan información en cuanto a $P$. cusickiana var. maguirei para investigaciones futuras y tienen implicaciones directas para la conservación de esta especie amenazada.

Mosses are an integral feature of many plant communities (Smith 1982, Frego 2007, Ren et al. 2010) and may affect the distribution and performance of vascular plants through both abiotic and biotic pathways. Mosses may influence the fine-scale abiotic environment experienced by vascular plants by increasing available soil moisture (Nilsson et al. 1996, Ren et al. 2010), stabilizing soil beds and accelerating the soil-building process (Burbank and Platt 1964, Bruno 2000), reducing soil temperature amplitudes (Van Cleve et al. 1983, Groeneveld et al. 2007), or intercepting and storing nutrients from throughfall and litter decomposition (Chapin et al. 1987, Sedia and Ehrenfeld 2003, Frego 2007). In terms of biotic interactions with other plants, mosses have both negative and positive interactions related to resource availability, seed germination and establishment, and seedling dynamics (e.g., During and Van Tooren 1990, Freestone 2006, Ren et al. 2010). Mosses may compete with vascular plant seedlings for limited soil moisture (Mallik et al. 1988, Serpe et al. 2006), and may interfere with seedling emergence via ground cover effects (Bai and Romo 1995, Donath and Eckstein 2010) or leached secondary compounds (Van Tooren 1990). Facilitation of nonvascular and vascular plants by bryophytes

\footnotetext{
${ }^{1}$ Department of Wildland Resources and The Ecology Center, Utah State University, 5230 Old Main Hill, NR 206, Logan, UT 84322-5230.

${ }^{2}$ Department of Biology, Utah State University, Logan, UT 84322-5305.
}

3Present address: Department of Plant Sciences, University of California-Davis, Davis, CA 95616. E-mail: aprayburn@ucdavis.edu 

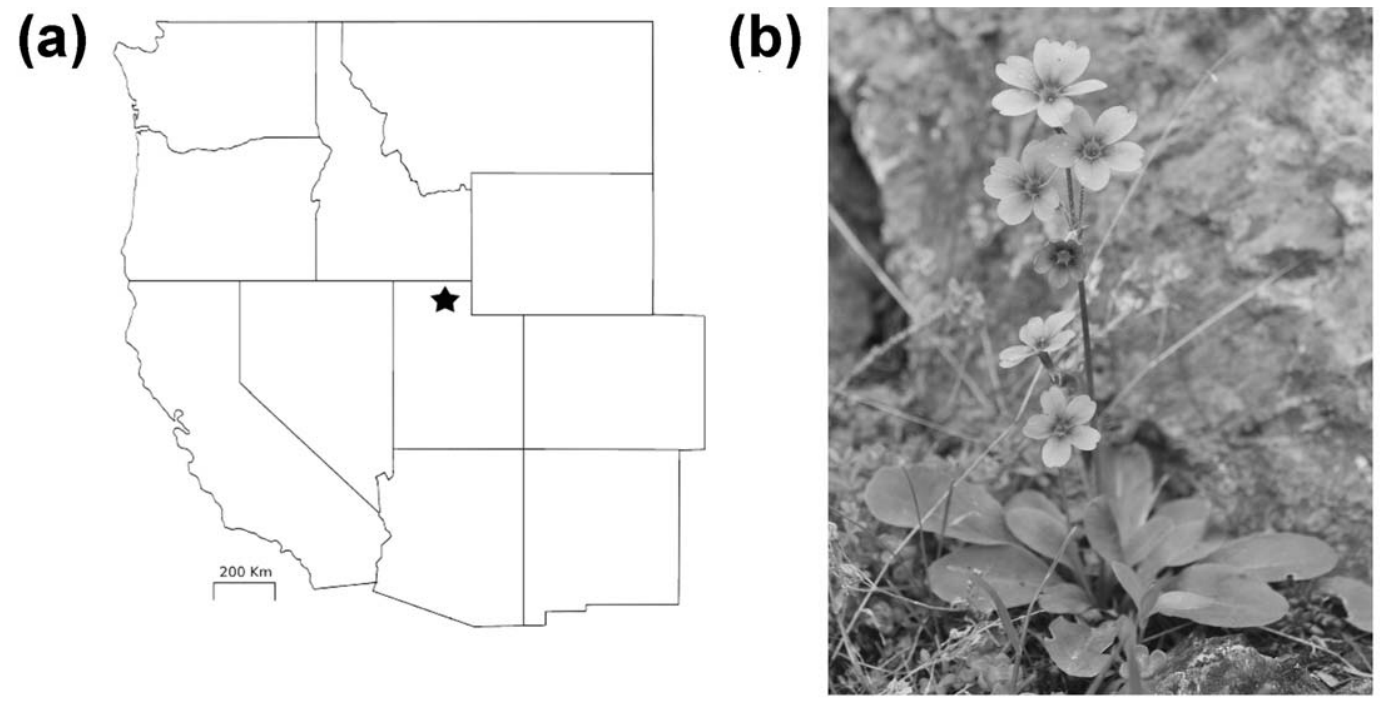

Fig. 1. Location of study site in northern Utah in the western United States (a) and representative photograph of Maguire primrose (Primula cusickiana var. maguirei) taken on-site in 2010 by H.M. White (b).

is an important driver of recruitment, local abundance, and regional distribution in some communities (e.g., Freestone 2006, Groeneveld et al. 2007, Ren et al. 2010). The potential facilitative effects of moss on vascular plants include the buffering of extreme abiotic conditions (Groeneveld et al. 2007, Ren et al. 2010), protection of seeds from herbivory (Van Tooren 1988, During and Van Tooren 1990), and seed trapping combined with provision of safe sites for seed germination (Van Tooren 1988, Freestone 2006, Groeneveld et al. 2007).

In this study, we investigated the effects of moss on the distribution and performance of the rare herb Maguire primrose (Primula cusickiana var. maguirei L.O. Williams [Holmgren and Kelso]; Holmgren and Kelso 2001). Primula cusickiana var. maguirei is an endemic, threatened perennial forb found only in moist pockets on shallow soils derived from dolomitic limestone along a $20 \mathrm{~km}$ stretch of Logan Canyon, Utah, USA (USFWS 1990, Wolf and Sinclair 1997, Kelso et al. 2009) (Fig. 1). Distinct populations of $P$. cusickiana var. maguirei occur in upper and lower portions of the canyon, separated by about $12 \mathrm{~km}$ of terrain in which no known populations occur (Bjerregaard and Wolf 2008, Davidson and Wolf 2011). Individual plants may have single or multiple stalks with between 1 and 6 flowers each, and plants may spread via rhizomes to form dense clones if conditions are suitable (Davidson and Wolf 2011). Flowers are approximately $2.5 \mathrm{~cm}$ in diameter (Williams 1936) and are characterized by the classic pin-thrum morphology found in many Primula species (Darwin 1877). Seeds of P. cusickiana var. maguirei are extremely small, with individual seeds weighing approximately $0.01 \mathrm{mg}$ (Bjerregaard and Wolf 2008).

Primula cusickiana var. maguirei is vulnerable to extinction due to its restricted range, its habitat specificity, and the small number of individual plants scattered through several known populations within its range (Wolf and Sinclair 1997). In addition, like other heterostylous members of Primula sect. Parryi, P. cusickiana var. maguirei is highly dependent on insect pollinators for successful cross-fertilization of floral morphs (Richards 2003, Kelso et al. 2009, Davidson and Wolf 2011). Many of these pollinators have limited foraging distances and are inconsistent in inclement weather or if plant populations shrink to levels at which floral displays become limited (Kelso et al. 2009). Populations of $P$. cusickiana var. maguirei are often separated by swaths of unsuitable terrain across which seed dispersal is unlikely, since dispersal is limited to short-distance transport by wind, water, and gravity (Kelso et al. 2009). The primrose is subject to frequent herbivory by snails of the Oreohelix genus (Davidson and Wolf 2011) and bushy-tailed woodrats (Neotoma cinerea) 
(Bjerregaard and Wolf 2008). The primrose is also potentially threatened by water development, recreation activities, specimen collection, and road construction (USFWS 1990).

At both upper and lower canyon locations, P. cusickiana var. maguirei has been observed in association with various species of moss, including Tortula princeps (Pottiaceae) and Weissia spp. (Pottiaceae) (Davidson and Wolf 2011). However, the effects of moss on the distribution and performance of $P$. cusickiana var. maguire $i$ are unknown, despite a suite of studies related to the genetics, reproduction, seed production, and regional distribution of the variety (Wolf and Sinclair 1997, Kelso et al. 2009, Davidson and Wolf 2011). We collected field data on the distribution and performance of $P$. cusickiana var. maguirei to investigate both the distribution of the primrose relative to moss and the effect of moss on primrose performance. Specifically, we sought to determine (1) if primroses occurred more often than expected on moss patches, as compared to other substrates, and (2) if primroses occurring on moss patches had significantly different basal area and flower number than primroses occurring on other substrates. We then sampled and analyzed soils within the study population to determine if the distribution of $P$. cusickiana var. maguire $i$ was correlated with specific soil characteristics and whether those soil characteristics were linked to different substrates.

\section{Methods}

\section{Primrose Distribution and Performance}

The study was conducted during peak flowering season in spring 2010 within a safely accessible, lower-canyon population of $P$. cusickiana var. maguirei. Upper-canyon populations were excluded from the study due to relative inaccessibility and because ground cover within upper-canyon populations is characterized almost exclusively by dense carpets of moss that precluded meaningful comparisons of substrates. In order to determine the relative availability of the different substrates on which primroses occurred, we established 8 variable-length transects across the study area-from edge to edge of the overall suitable habitat-and used the standard line-intercept method to record substrate (bare ground, bare rock, rock crack, or moss). We surveyed plants by randomly laying three $10-\mathrm{m}$ transects within the population and including all individuals within $1 \mathrm{~m}$ of each transect. Because the species spreads clonally as well as by seed, we distinguished $P$. cusickiana var. maguirei individuals on the basis of flower morphology and the presence or absence of rhizomes. The substrate on which each plant occurred was recorded (bare ground, rock crack, or moss), as was the basal area and the number of flowers.

We analyzed distribution data with a one-way chi-square goodness of fit test in SAS 9.22 (SAS Institute, Inc.). Rock outcrop had by far the greatest cover of the overall habitat (42.9\%), but this habitat is completely unsuitable for primrose. Therefore, the expected frequencies used in the chi-square analysis were based only on relative cover from the line-intercept data of the 3 microhabitat types where primrose occurrence was possible (65.7\% bare ground, $26.7 \%$ moss, and $7.7 \%$ rock crack). Using the PROC GLIMMIX procedure in SAS, we analyzed the relationship between basal area and substrate type with a one-way ANOVA for a completely randomized design, with a Tukey-Kramer adjustment for multiple comparisons. The area variable was log-transformed to stabilize the variance, and a heterogeneous variance model was used for the different levels of substrate. We analyzed the relationship between flower number and substrate type as a one-way factorial in a generalized linear model for a completely randomized design in PROC GLIMMIX. A negative binomial distribution was fitted in conjunction with a log-link, and a Tukey-Kramer adjustment was used for multiple comparisons.

\section{Soil Moisture and Nutrients}

Soil moisture samples were collected from 10 randomly selected sites ( 5 bare ground, 5 moss) in mid-June 2010, immediately following a significant rain event (approximately $0.8 \mathrm{~cm}$ ). We collected samples from 10 additional randomly selected sites ( 5 bare ground, 5 moss) approximately 3 weeks after the precipitation event, a period during which no significant precipitation occurred. In both instances, samples were taken from the upper $5 \mathrm{~cm}$ of the soil profile. On moss sites, soil was taken from directly beneath moss patches. Soil water content was collected using the gravimetric method: samples were weighed wet, air-dried, and weighed dry $\left(\Theta_{\mathrm{m}}=\right.$ water weight / sample dry weight). For each of the 2 sampling periods, mean soil water content for each substrate was compared in 


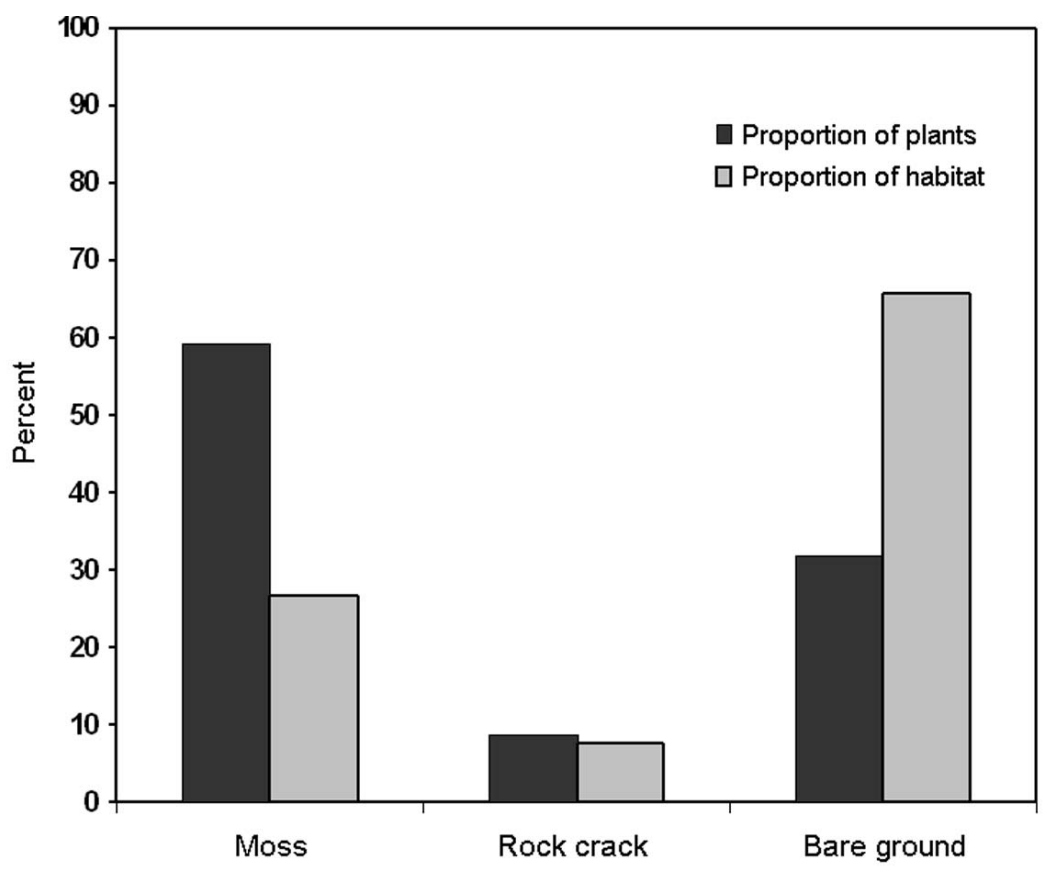

Fig. 2. Proportion (0\%-100\%) of Primula cusickiana var. maguirei plants that occurred on each substrate (moss, rock crack, and bare ground) and the proportion of total habitat represented by each substrate.

PROC GLIMMIX using a one-way ANOVA for a completely randomized design. Moisture variables were log-transformed to improve normality and to stabilize the variance.

For nutrient analyses, 5 samples were collected from the upper $5 \mathrm{~cm}$ of the soil profile from 4 randomly selected location types (bare ground, bare ground with primrose present, moss patch, moss patch with primrose present). Soil nutrient analyses were conducted during summer 2010 at the Utah State University Analytical Laboratories, and consisted of tests for plant available $\mathrm{N}\left(\mathrm{Ca}[\mathrm{OH}]_{2}\right.$ extract), organic matter (Walkley-Black), and water-soluble cations ( $\mathrm{Ca}, \mathrm{Mg}, \mathrm{Na}, \mathrm{K}$; ammonium acetate extract). Mean nutrient concentrations across substrates were analyzed in PROC GLIMMIX using a one-way ANOVA for a completely randomized design with a Tukey-Kramer adjustment, and response variables were once again log-transformed to improve normality and to stabilize the variance. The results of this analysis in regards to $\mathrm{Mg}$ suggested an interaction between moss patches and P. cusickiana var. maguirei; we examined this interaction using a post hoc 2-way ANOVA with categorical predictor variables (binary presence/absence codes for moss and P. cusickiana var. maguirei) and log-transformed $\mathrm{Mg}$ nutrient concentrations as the response variable.

\section{RESULTS}

\section{Primrose Distribution and Performance}

A total of 150 individual primrose plants were surveyed along the 3 transects. Eighty-nine primroses occurred on moss, whereas 48 primroses occurred on bare ground and 13 occurred in rock cracks. Primroses occurred far more often on moss patches than expected if the 3 possible substrates were utilized equally $\left(\chi^{2}=\right.$ 86.15, $P<0.0001$; Fig. 2).

Primroses occurring on moss patches had a significantly greater mean basal area than those occurring on bare ground (adj. $P<0.005$; Fig. 3a). There was not a significant difference in mean basal area between primroses occurring on moss and those occurring in rock cracks, nor was there a significant difference between primroses occurring in rock cracks and those occurring on bare ground. Primroses occurring on moss also had a greater mean number of flowers than those occurring on bare ground (adj. $P<$ 0.0001; Fig. 3b). There was not a significant 

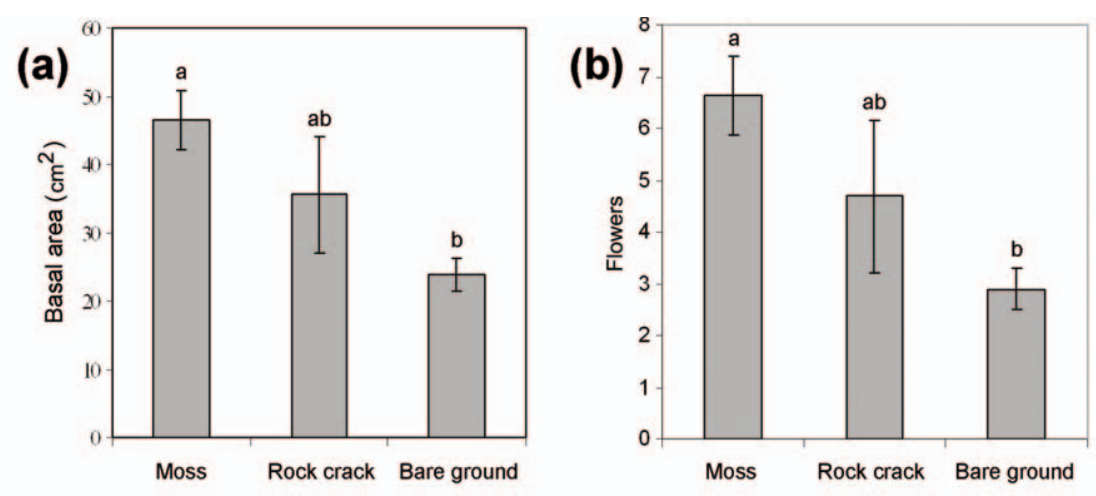

Fig. 3. Basal area (a) and number of flowers (b) for Primula cusickiana var. maguirei plants occurring on moss, rock crack, and bare ground. Error bars represent one standard error around the mean. Unique letters represent statistically significant differences $(P>0.05)$.

difference in flower number between primroses occurring on moss and those occurring in rock cracks, nor was there a significant difference between primroses occurring in rock cracks and those occurring on bare ground.

\section{Soil Moisture and Nutrients}

There was not a significant difference in mean soil water content between soil under moss (mean $\Theta_{\mathrm{m}}=0.46$ ) and bare ground soil (mean $\left.\Theta_{\mathrm{m}}=0.47\right)$ immediately following a major precipitation event. However, soil under moss retained more moisture (mean $\left.\Theta_{\mathrm{m}}=0.14\right)$ after approximately 3 weeks of warm, dry spring weather as compared to bare ground soil (mean $\left.\Theta_{\mathrm{m}}=0.02 ; P=0.001\right)$.

Mean percentages of organic matter varied significantly among substrates $(P<0.001)$, and there was significantly more organic matter in soil beneath moss with primrose present $(24.48 \%)$ than in soil from bare ground $(10.90 \%$; adj. $P=0.001)$, soil from bare ground with primrose present (13.34\%; adj. $P=0.009$ ), and soil from moss patches lacking primrose $(8.5 \%$; adj. $P<0.0001)$.

Mean concentrations of $\mathrm{Mg}$ also varied significantly among substrates $(P=0.002)$, and there were significantly higher concentrations of $\mathrm{Mg}$ (expressed as centimoles of charge per

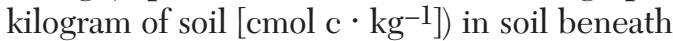
moss with primrose present $\left(52.29 \mathrm{cmol} \mathrm{c} \cdot \mathrm{kg}^{-1}\right)$ than in soil from bare ground $(29.21 \mathrm{cmol} \mathrm{c}$. $\mathrm{kg}^{-1}$; adj. $\left.P=0.007\right)$, soil from bare ground with primrose present $\left(32.75 \mathrm{cmol} \mathrm{c} \cdot \mathrm{kg}^{-1}\right.$; adj. $P=$ $0.04)$, and soil from moss patches lacking prim-

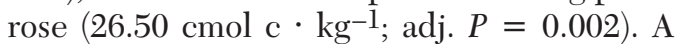

post hoc test (see methods) revealed both a significant main effect of primrose $(P=0.0015)$ and a significant moss $\times$ primrose interaction $(P=0.0170)$ relative to the mean concentration of $\mathrm{Mg}$. Mean concentrations of plant-available Ca did not vary significantly among the 4 substrate categories $(P>0.10)$; however, mean $\mathrm{Ca}: \mathrm{Mg}$ ratios were significantly lower in soil beneath moss with primrose present $(0.042: 1)$ than in soil from bare ground $(0.062: 1$; adj. $P=$ $0.0003)$, soil from bare ground with primrose present (0.063:1; adj. $P=0.0003)$, and soil from moss patches lacking primrose $(0.060: 1$; adj. $P=$ $0.001)$. Mean concentrations of plant-available $\mathrm{N}$, Na, and $\mathrm{K}$ did not vary significantly among the 4 substrate categories $(P>0.05)$.

\section{Discussion}

Mosses are important components of ecological communities and may have a wide range of interactions with vascular plants (During and Van Tooren 1990, Sedia and Ehrenfeld 2003, McMullan-Fisher et al. 2010). We found that P. cusickiana var. maguirei individuals occurred on moss patches more often than expected by chance relative to other substrates within the population under study, and that individuals occurring on moss had significantly greater basal area and flower number than those occurring on other substrates. Although broader-scale observational research (e.g., conducting similar studies in additional populations) coupled with experimental field studies (e.g., moss removal, seedling addition) will be required to conclusively demonstrate facilitation by moss of 
P. cusickiana var. maguirei within its narrow canyon range, our results suggest that moss may affect the primrose's distribution and positively influence its performance.

Spring conditions in the study canyon are cool and moist with the potential for freezing temperatures, and field observations confirm that Maguire primrose seedlings emerge during this time (Davidson and Wolf 2011). If facilitation of $P$. cusickiana var. maguirei by moss occurs during this period, it is likely via the provision of safe sites for P. cusickiana var. maguirei seed germination and establishment as observed in other plant communities (Hörnberg et al. 1997, Kirkpatrick et al. 2006, Ren et al. 2010). Moss may also buffer emergent seedlings from extreme fluctuations in temperature (Groeneveld et al. 2007), although the response of $P$. cusickiana var. maguirei seedlings to temperature extremes is unknown. During the early portion of the growing season when soil moisture is unlikely to be limiting, seedlings may also benefit from the increased availability of organic matter under certain moss patches, which provides nutrients to plants through decomposition and contributes to the cation exchange complex that acts to retain soil nutrients (Allison 1973, Tiessen et al. 1994). The primrose may also be dependent on magnesium carbonates derived from dolomitic bedrock on which populations tend to occur (USFWS 1990, Dover 1995), and seedlings may therefore benefit from the increased availability of $\mathrm{Mg}$ we detected under selected moss patches. Generally, mosses have important effects on soil nutrient concentrations and availability (Snyder and Wullstein 1973, Frego 2007). The processes leading to Mg accumulation in soil beneath moss patches with primrose present are unknown; however, we suspect that weathering of exposed bedrock by moss may have led to accumulation of $\mathrm{Mg}$ under certain moss patches that were preferentially colonized by the primrose. Mosses are known to accelerate weathering of carbonate rocks, leading to the dissolution and release of $\mathrm{Mg}$ and other elements into the soil (Bin et al. 2008). We observed the lowest Mg concentrations under moss patches lacking $P$. cusickiana var. maguirei, suggesting that $\mathrm{Mg}$ does not accumulate under all moss patches to the same degree; the results of our post hoc analysis support this conclusion, given the significant main effect of primrose presence on $\mathrm{Mg}$ concentrations irrespective of moss presence. In conjunction with weathering, elevated concentrations of $\mathrm{Mg}$ in soil under moss patches with primrose present may have resulted from decomposition of moss and/or primrose plant tissue in which Mg had previously accumulated. The significant moss $\times$ primrose interaction that we detected supports this hypothesis and suggests that both moss and primrose are either jointly responsible for elevated $\mathrm{Mg}$ concentrations (e.g., through microbially mediated pathways) or are both responding to a patchy distribution of elevated $\mathrm{Mg}$ already present in the soil. Interestingly, the $\mathrm{Ca}: \mathrm{Mg}$ ratios calculated for soil samples in this study (range 0.042:1 to 0.063:1) were dramatically lower than Ca:Mg ratios assumed for typical soil (often $>1: 1$; Epstein 1972) and are similar to those found in serpentine soils (Bradshaw 2005, Murren et al. 2006). In conjunction with other factors such as low water availability, extreme soil conditions such as elevated Mg and low Ca:Mg ratios may exert strong selection pressures that act to shape the distribution and fitness of locally adapted plant taxa (Brady et al. 2005, Murren et al. 2006), and we hypothesize that both factors may have contributed to the localized endemism of P. cusickiana var. maguirei. We recommend that future studies evaluate the effect of elevated $\mathrm{Mg}$ and low $\mathrm{Ca}: \mathrm{Mg}$ ratios on the growth of P. cusickiana var. maguirei. As primroses mature and flower, precipitation rapidly declines with the onset of early summer. If facilitation of $P$. cusickiana var. maguirei by moss occurs in this period, it is likely in the form of increased soil moisture in addition to soil nutrients. Increased soil moisture under some moss patches may result from reduced evaporation (since soil is covered by moss and not directly exposed to the air) and increased water retention by soil due to increased organic matter (Rawls et al. 2003). In other water-limited plant communities, researchers have found that soil moisture availability during growing seasons is often higher under moss patches than in surrounding substrates (Snyder and Wullstein 1973, Ren et al. 2010). Primrose occurring in rock cracks might also benefit from increased moisture availability due to reduced evaporation and water accumulation, although we did not find significant differences in flower number or basal area for primroses in rock cracks as compared to other substrates (Fig. 3).

An alternative explanation for the observed tendency of primrose to occur on moss patches 
is that primrose seeds may be preferentially trapped in moss patches relative to other substrates. Seed-trapping results from the complex biological structure of moss leaves and stems that intercept seeds that may otherwise fail to reach safe sites for germination (Callaway 1995, Levine and Murrell 2003, Freestone 2006). In our study system, seeds of mature P. cusickiana var. maguirei occurring on moss patches may fall and potentially be trapped on the same patch, while seeds of mature plants occurring on other substrates may move horizontally or downslope via gravity, wind, or water before being trapped by moss patches or some other obstacle. Seeds might also be preferentially trapped in rock cracks, although we did not find any statistical evidence that primroses occurred more often in rock cracks than on bare ground. While the miniscule size of $P$. cusickiana var. maguire $i$ primrose seeds precluded any direct assessment of the potential for mosses to trap them, future research could address this question through controlled tests of the ability of moss to trap either primrose seed or appropriate seed analogs. However, seed trapping alone does not adequately explain our findings of increased basal area and flower number for primrose occurring on moss patches.

We suggest a third explanation for our results, namely that both mosses and $P$. cusickiana var. maguirei are responding to some unmeasured habitat factor that leads to their co-occurrence and to the increased performance of P. cusickiana var. maguirei. Such factors could be seeps of water through rock cracks, microtopography, protection from wind, or soil depth. Future field studies involving manipulative experiments (e.g., Freestone 2006, Ren et al. 2010) will be required to conclusively demonstrate facilitation by moss of P. cusickiana var. maguirei and to better understand the factors that influence the primrose's distribution and performance.

\section{Conservation Implications}

The plant flora of Utah is diverse, with many locally endemic species having restricted distributions (Welsh et al. 1975, Welsh and Chatterley 1985). Local endemism is common in the North American Intermountain West, where related allopatric taxa may be restricted to specialized habitats (Harper and Reveal 1978, Reveal 1979, Kelso et al. 2009). In species-rich genera such as Primula and Penstemon, widespread species may have recently derived endemic relatives often restricted to narrow ranges by elevation or substrate (Kelso et al. 2009). Many endemic plant species in Utah are threatened or endangered, and conservation of $P$. cusickiana var. maguirei and other species is challenging due to limited dispersal or migration, small populations, reproductive restrictions, anthropogenic activities, and climatic predictions (Welsh et al. 1975, Kelso et al. 2009).

The species recovery plan developed for P. cusickiana var. maguirei includes proposals to fully map and inventory existing populations (USFWS 1990); and the knowledge that the primrose tends to occur in association with moss may lead to more efficient location and mapping of additional populations throughout its canyon range. The species recovery plan also calls for the development of strategies to establish and maintain new populations (USFWS 1990). Paramount to these strategies is the identification of potential habitat in which new populations of $P$. cusickiana var. maguire $i$ could be established (USFWS 1990). Plant reintroduction is a common strategy for preventing the extinction of rare plant species, and reintroduction biology is often concerned with factors affecting population establishment and persistence (Godefroid et al. 2010, Ren et al. 2010). While this study does not conclusively demonstrate a facilitative effect of moss on P. cusickiana var. maguirei, our results suggest that use of moss patches may increase the effectiveness of future reintroduction efforts for the primrose, because moss patches may be targets for direct seeding or seedling transplant efforts. In the past 2 decades, there has been increased recognition of the potential for including positive plant interactions in conservation and restoration planning (Padilla and Pugnaire 2006, Halpern et al. 2007, Ren et al. 2010) in a diverse range of communities, including high mountains (Aerts et al. 2007), tropical forests (Parrotta et al. 1997), and Mediterranean shrublands (Gómez-Aparicio et al. 2004) among many others (see Padilla and Pugnaire 2006, Gómez-Aparicio 2009). Positive plant interactions may play especially important roles in maintaining populations of rare plants whose persistence in harsh environments depends critically on the benefits derived from association with other plant species (Freestone 2006, Ren et al. 2010). The specific role of mosses in facilitating plant reintroduction also has received increased 
attention (e.g., Groeneveld et al. 2007, Ren et al. 2010) due to the potential for moss to increase moisture and nutrient availability, stabilize soil substrates, and protect seeds and seedlings from herbivory. Future studies could address the potential for moss to facilitate reintroduction of $P$. cusickiana var. maguirei through seedling-addition experiments. Such research would be especially salient given that a recently published review of plant reintroduction efforts found that survival, flowering, and fruiting rates of 249 reintroduced plant species were low enough to be of significant concern (Godefroid et al. 2010).

\section{ACKNOWLEDGMEnTS}

APR was supported by a research grant from Sigma Xi; and APR, JBD, and HMW were supported by a research grant from the Utah Native Plant Society. We thank P.G. Wolf and E.W. Schupp for insightful comments on sampling design and early drafts of this manuscript, J. Boettinger for advice on interpretation of soil analyses, and S. Durham for help with statistical analyses.

\section{Literature Cited}

Aerts, R., A. Negussie, W. Maes, E. November, M. Hermy, AND B. MuYs. 2007. Restoration of dry Afromontane forest using pioneer shrubs as nurse-plants for Olea europaea ssp. cuspidata. Restoration Ecology 15:129-138.

AlLison, F.E. 1973. Soil organic matter and its role in crop production. Elsevier, New York, NY.

BAI, Y., AND J.T. Romo. 1995. Seedling emergence of Artemisia frigida in relation to hydration-dehydration cycles and seedbed characteristics. Journal of Arid Environments 30:57-65.

Bin, L., C. YE, Z. Lijun, AND Y. Ruidong. 2008. Effect of microbial weathering on carbonate rocks. Earth Science Frontiers 15:90-99.

Bjerregatrd, L., AND P.G. Wolf. 2008. Strong genetic differentiation among neighboring populations of a locally endemic primrose. Western North American Naturalist 68:66-75.

BradshaW, H.D., JR. 2005. Mutations in CAX1 produce phenotypes characteristic of plants tolerant to serpentine soils. New Phytologist 167:81-88.

Brady, K.U., A.R. Kruckeberg, and H.D. Bradshaw Jr. 2005. Evolutionary ecology of plant adaptation to serpentine soils. Annual Review of Ecology, Evolution, and Systematics 26:243-266.

BRUNO, J.F. 2000. Facilitation of cobble beach plant communities through habitat modification by Spartina alterniflora. Ecology 81:1179-1192.

Burbank, M.P., and R.B. Platt. 1964. Granite outcrop communities of the Piedmont Plateau in Georgia. Ecology 45:292-306.
Callaway, R.M. 1995. Positive interactions among plants. Botanical Review 61:306-349.

Chapin, F.S., III, W.C. Oechel, K. Van Cleeve, and W. LaWrence. 1987. The role of mosses in the phosphorus cycling of an Alaskan black spruce forest. Oecologia 74:310-315.

DARWIN, C. 1877. The different forms of flowers on plants of the same species. Murray, London.

Davidson, J.B., AND P.G. WOLF. 2011. Natural history of Maguire primrose, Primula cusickiana var. maguirei (Primulaceae). Western North American Naturalist 71:327-337.

Donath, T.W., And R. Lutz Eckstein. 2010. Effects of bryophytes and grass litter on seedling emergence vary by vertical seed position and seed size. Plant Ecology 207:257-268.

Dover, J.H. 1995. Geologic map of the Logan $30^{\prime} \times 60^{\prime}$ quadrangle, Cache and Rich counties, Utah, and Lincoln and Uinta counties, Idaho. Map I-2210, Miscellaneous Investigation Series, U.S. Geological Survey, Denver, CO.

During, H.J., AND B.F. VAN ToOren. 1990. Bryophyte interactions with other plants. Botanical Journal of the Linnean Society 104:79-98.

EPSTEIn, E. 1972. Mineral nutrition of plants: principles and perspectives. Wiley \& Sons, Inc., New York, NY.

Freestone, A.L. 2006. Facilitation drives local abundance and regional distribution of a rare plant in a harsh environment. Ecology 87:2728-2735.

Frego, K.A. 2007. Bryophytes as potential indicators of forest integrity. Forest Ecology and Managment 242: 65-75.

Godefroid, S., C. Piazza, G. Rossi, S. Buord, A. Stevens, R. Aguraiuja, C. Cowell, C.W. Weekley, G. VogG, J.M. IrIONDO, ET AL. 2010. How successful are plant species reintroductions? Biological Conservation 144:672-682.

Gómez-Aparicio, L. 2009. The role of plant interactions in the restoration of degraded ecosystems: a metaanalysis across life-forms and ecosystems. Journal of Ecology 97:1202-1214.

Gómez-Aparicio, L., R. Zamora, J.M. Gómez, J.A. Hódar, J. CASTRo, AND E. BARAZA. 2004. Applying plant positive interactions to reforestation in Mediterranean mountains: a meta-analysis of the use of shrubs as nurse plants. Ecological Applications 14:1128-1138.

Groeneveld, E.V.G., A. Massé, and L. Rochefort 2007. Polytrichum strictum as a nurse-plant in peatland restoration. Restoration Ecology 15:709-719.

Halpern, B.S., B.R. Silliman, J.D. Olden, J.P. Bruno, M.D. BERTNESS. 2007. Incorporating positive interactions in aquatic restoration and conservation. Frontiers in Ecology and the Environment 5:153-160.

HARPER, K.T., AND J.L. REVEAL, EDITORS. 1978. Intermountain biogeography: a symposium. Great Basin Naturalist Memoirs 2:1-268.

Holmgren, N.H., And S. Kelso. 2001. Primula cusickiana (Primulaceae) and its varieties. Brittonia 53:154-156.

HÖrnberg, G., M. OHLSON, AND O. ZaCKrisson. 1997. Influence of bryophytes and microrelief conditions on Picea abies seed regeneration patterns in boreal oldgrowth swamp forests. Canadian Journal of Forest Research 27:1015-1023.

Kelso, S., P.M. Beardsley, and K. Weitemier. 2009. Phylogeny and biogeography of Primula sect. Parryi (Primulaceae). International Journal of Plant Sciences 170:93-106. 
Kirkpatrick, H.E., J.W.S. Barnes, AND B.A. Ossowski. 2006. Moss interference could explain the microdistributions of two species of monkey-flowers (Mimulus, Scrophulariaceae). Northwest Science 80:1-8.

Levine, J.M., AND D.J. MurReLL. 2003. The communitylevel consequences of seed dispersal patterns. Annual Review of Ecology Evolution and Systematics 34: 549-574.

Mallik, A.U., R.J. Hobbs, And A.A. Rahman. 1988. Seedbed substrates and revegetation of Calluna heathlands following burning. Journal of Environmental Management 27:379-398.

McMullan-Fisher, S.J.M., J.B. Kirkpatrick, T.W. May, AND E.J. Pharo. 2010. Surrogates for macrofungi and mosses in reservation planning. Conservation Biology 24:730-736.

Murren, C.J., L. Douglass, A. Gibson, and M.R. Dudash. 2006. Individual and combined effects of $\mathrm{Ca} / \mathrm{Mg}$ ratio and water on trait expression in Mimulus guttatus. Ecology 87:2591-2602.

Nilsson, M.C., I. Steijlen, and O. Zackrisson. 1996. Time-restricted seed regeneration of Scots pine in sites dominated by feathermoss after clear-cutting. Canadian Journal of Forest Research 26:945-953.

Padilla, F.M., AND F.I. Pugnaire. 2006. The role of nurse plants in the restoration of degraded environments. Frontiers in Ecology and the Environment 4:196-202.

Parrotta, J.A., J.W. Turnbull, And N. Jones. 1997. Catalyzing native forest regeneration of degraded tropical lands. Forest Ecology and Management 99:1-7.

Rawls, W.J., Y.A. PachePsky, J.C. Ritchie, T.M. Sobecki, AND H. BLOODWORTH. 2003. Effect of soil organic carbon on soil water retention. Geoderma 116:61-76.

Ren, H., G. Ma, Q. Zhang, Q. GUO, J. WANG, AND Z. WANG. 2010. Moss is a key nurse plant for reintroduction of the endangered herb, Primulina tabacum. Plant Ecology 209:313-320.

REvEAL, J.L. 1979. Biogeography of the Intermountain region. Mentzelia 1979:1092.

Richards, A.J. 2003. Primula. Timber Press, Portland, OR.

Sedia, E.G., AND J.G. Ehrenfeld. 2003. Lichens and mosses promote alternate stable plant communities in the New Jersey Pinelands. Oikos 100:447-458.
Serpe, M.D., J.M. Orm, T. Barkes, and R. Rosentreter. 2006. Germination and seed water status of four grasses on moss-dominated biological crusts from arid lands. Plant Ecology 185:163-178.

Smith, A.J.C. 1982. Bryophyte ecology. Chapman and Hall, London.

SNYDER, J.M., AND L.H. WuLLSTEIN. 1973. Nitrogen fixation on granite outcrop pioneer ecosystems. Bryologist 76:196-199.

Tiessen, H., E. Cuevas, And P. Chacon. 1994. The role of soil organic matter in sustaining soil fertility. Nature 371:783-785.

[USFWS] United States Fish and Wildlife Service. 1990. Maguire primrose (Primula maguirei) recovery plan. Denver, CO.

Van Cleve, K., C.T. Dyrness, L.A. Viereck, J. Fox, F.S. Chapin, AND W. OEchel. 1983. Taiga ecosystems in interior Alaska. Bioscience 33:39-44.

VAN ToOREN, B.F. 1988. The fate of seeds after dispersal in chalk grasslands: the role of the bryophyte layer. Oikos 53:41-48.

1990. Effects of a bryophyte layer on the emergence of seedlings of chalk grassland species. Acta Oecologica 11:155-163.

Welsh, S.L., N.D. Atwood, and J.L. Reveal. 1975. Endangered, threatened, extinct, endemic, and rare or restricted Utah vascular plants. Great Basin Naturalist 35:327-376.

Welsh, S.L., AND L.M. Chatterley. 1985. Utah's rare plants revisited. Great Basin Naturalist 45:173-236.

Williams, L.O. 1936. Revision of the western primulas. American Midland Naturalist 17:741-748.

Wolf, P.G., AND R.B. SincLaIR. 1997. Highly differentiated populations of the narrow endemic plant Maguire primrose (Primula maguirei). Conservation Biology 11:375-381.

Received 16 May 2011 Accepted 25 January 2012 